\title{
Psychometric properties of the Polish version of the Children's Auditory Performance Scale
}

\section{Właściwości psychometryczne polskiej adaptacji Skali Oceny Przetwarzania Słuchowego u Dzieci}

\author{
Katarzyna Bieńkowska ${ }^{1, A-D \oplus}$, Elżbieta Gos ${ }^{1, C-D, F \oplus}$, Piotr Henryk Skarżyński ${ }^{1,2, A, F \oplus ~}$ \\ ${ }^{1}$ Institute of Physiology and Pathology of Hearing, World Hearing Centre, Poland \\ ${ }^{2}$ Institute of Sensory Organs, World Hearing Centre, Poland \\ A - Research concept and design, B - Collection and/or assembly of data, C - Data analysis and interpretation, \\ $D$ - Writing the article, E - Critical revision of the article, F - Final approval of article
}

Bieńkowska K, Gos E, Skarżyński PH. Psychometric properties of the Polish version of the Children's Auditory Performance Scale. Med Og Nauk Zdr. 2020; 26(3): 261-267. doi: 10.26444/monz/126461

\section{Abstract}

Introduction and objectives. The key element of the diagnostics of Auditory Processing Disorder (APD) is assessment of peripheral hearing and higher auditory functions, supplemented by information from clinical history-taking. Also, specialist questionnaires play an important role. The aim of the study was presentation of the psychometric properties of the Polish version of the Children's Auditory Performance Scale (CHAPS), and verification of the usefulness of this questionnaire in the diagnostics of auditory processing disorders.

Materials and method. The study included 176 parents of children aged between 7-12 years. The CHAPS questionnaire consists of 36 items divided into 6 categories (subscales), referring to various auditory behaviours. The respondent's task was to specify the way of functioning of children, compared to their contemporaries; the higher the result, the better the auditory skills. The Scale of Auditory Behaviors (SAB) was applied, and psychoacoustic behavioural tests were performed. Results. Reliability of measurements was found to be good, Cronbach's alpha coefficient (0.97) showed a high internal consistency of the scale. Statistically significant, positive correlations were observed between the total score and subscales (0.58-0.7). Intra-class correlation, which was used to determine reproducibility, was 0.84 . Correlations with the results of psychoacoustic tests were low (0.2-0.3), and with Scale of Auditory Behaviors - 0.62. Statistically significant differences between girls and boys were found in the total score; however, no statistically significant relationship was noted between the child's age and the CHAPS results.

Conclusions. Results of psychometric and statistical analyses suggest that the Polish version of the Children's Auditory Performance Scale enables a reliable measurement of hearing and understanding difficulties in children. The questionnaire may be useful in the diagnostics of auditory performance disorders.

\section{Key words}

Auditory Processing Disorder, questionnaires, diagnosis, children

Address for correspondence: Elżbieta Gos, Institute of Physiology and Pathology of Hearing, World Hearing Centre, Poland

E-mail: e.gos@ifps.org.pl

Received: 05.06.2020; accepted: 18.08.2020; first published: 04.09.2020

\section{Streszczenie}

Cel pracy. Kluczowym elementem diagnostyki zaburzeń przetwarzania słuchowego jest ocena słuchu obwodowego oraz wyższych funkcji słuchowych, uzupełniona informacjami z wywiadu klinicznego. Ważną rolę odgrywają także specjalistyczne kwestionariusze. Cel pracy stanowi zaprezentowanie właściwości psychometrycznych polskiej wersji Skali Oceny Przetwarzania Słuchowego u Dzieci (CHAPS - Children's Auditory Performance Scale) oraz weryfikacja przydatności tego kwestionariusza w diagnostyce zaburzeń przetwarzania słuchowego.

Materiał i metody. W badaniu wzięło udział 176 rodziców dzieci wieku od 7 do 12 lat. Kwestionariusz CHAPS składa się z 36 pozycji podzielonych na 6 kategorii (podskal), odnoszących się do różnych zachowań słuchowych. Zadaniem respondenta jest określenie, w jaki sposób dziecko funkcjonuje w porównaniu z rówieśnikami. Im wyższy wynik, tym lepsze umiejętności słuchowe. W badaniu zastosowano także Skalę Zachowań Słuchowych (SAB - Scale of Auditory Behaviors) i Kwestionariusz Trudności Słuchowych Dziecka (CHILD) oraz przeprowadzono behawioralne testy psychoakustyczne. Wyniki. Współczynnik alfa Cronbacha 0,97 dla polskiej wersji CHAPS wskazuje na wysoką spójność wewnętrzną narzędzia. Zaobserwowano także istotne statystycznie pozytywne korelacje (od 0,58 do 0,7) między wynikami podskal a wynikiem ogólnym. Korelacje z wynikami testów psychoakustycznych zawierały się w przedziale 0,2-0,3, korelacja z kwestionariuszem $S A B$ wyniosła 0,62. Istotne różnice między dziewczynkami a chłopcami ujawniły się w wyniku ogólnym. Brak było istotnej zależności między wiekiem dziecka a wynikami CHAPS.

Wnioski. Wyniki analiz statystycznych i psychometrycznych wskazują, że polska wersja kwestionariusza CHAPS umożliwia rzetelny pomiar trudności w słyszeniu i rozumieniu u dzieci. Kwestionariusz może być przydatny w diagnostyce zaburzeń przetwarzania słuchowego.

\section{Słowa kluczowe}

dzieci, diagnoza, kwestionariusz, zaburzenia przetwarzania słuchowego 


\section{INTRODUCTION}

According to the definition by the American SpeechLanguage-Hearing Association (ASHA) Working Group of Auditory Processing Disorders [1], auditory processing disorder (APD) is characterized by abnormal processing of acoustic information on the level of the central nervous system, occurring despite the normal anatomical structure and adequate functioning of the anatomical peripheral part. APD covers observable disorders of mechanisms and processes (one or more) associated with acoustic behaviours, such as: sound localization and lateralization, auditory discrimination, ability to receive distorted signals, time perception of the signal, and recognition of sound features [2]. The symptoms evidencing deficits concerning auditory processing may be difficulties with understanding of: fast and indistinct speech, in noise conditions, expanded extensive verbal commands, as well as problems with auditory attention concentration, and being easily distracted [3-6].

Epidemiological studies show that APD occurs in approximately $2-3 \%$ of children, and $10-20 \%$ of the population of adults [7-9]. Etiopathogenesis of this disorder is complex. The following factors are indicated as conducive to the occurrence of APD: genetic background, lesions within the central nervous system, perinatal damage, as well as chronic otitis media, improper treatment of hearing loss, and too late laryngological interventions $[4,10]$.

Despite the prevalence of the problem of auditory processing disorders, until today in Poland, standards for diagnostic-therapeutic management have not been harmonized. Currently, the diagnostics of APD is based on the cooperation of specialists in various domains: audiologists, laryngologists, psychologists, pedagogues, speech therapists, and hearing aid technicians [11-14]. The key element of the diagnostics is performance of audiology tests in order to assess the functioning of peripheral hearing. In addition, psychoacoustic tests are performed, which measure: time aspects of processing acoustic information, auditory memory, integration and cross-ear separation, discrimination and distorted speech recognition thresholds [2]. Additionally, an assessment of cognitive and emotional functioning, as well as verbal communication are considered. In the diagnosis of auditory processing disorder it is important to differentiate, whether we deal exclusively with APD, or with concomitant disorders. Additional developmental or behavioural disorders diagnosed may considerably affect the outcomes of auditory processing tests. Therefore, it is important to perform the differential diagnostics by a team of specialists and, if possible, to make an unequivocal diagnosis $[12,14]$.

In order to assess the auditory functioning of a child more precisely, clinical history is supplemented with information obtained from parents or teachers based on questionnaires $[5,15-17]$. This enables the recognition of the perspectives for the functioning of a child in home and school conditions To-date in Poland, the adaptation of the Scale of Auditory Behaviours (SAB) has been developed and used for screening assessment of auditory processing disorders [18] however, this tool should not be applied in the comprehensive diagnostics of hearing difficulties.

The list of the questionnaires recommended by the American Speech-Language-Hearing Association, and the American Audiology Society [19], which enable the assessment of individual hearing behaviours in various acoustic conditions, includes, among others, the Children's Auditory Performance Scale (CHAPS), previously, CHAPPS: Children's Auditory Processing Performance Scale. This tool was developed by Smoski et al. [20], based on hearing difficulties most frequently observed in a group of 64 children aged 7.1-11.8 years diagnosed with auditory processing disorder [21]. CHAPS may be completed by parents, legal caregivers or teachers with respect to children aged at least 7 years. The tool consists of 36 items divided into 6 categories: hearing behaviours in conditions of noise, silence, in ideal acoustic conditions, with additional external stimuli, auditory memory, and auditory attention. The respondent's task is to specify the way of functioning of the child, compared to other children at similar age and from a similar environment. The answers are provided according to a 7-degree Likert scale, from -5 (cannot function at all) to +1 (less difficulty). The results are calculated separately for each subscale, and for the whole scale by averaging the numerical values ascribed to the replies; the higher the result, the better the auditory skills.

Smoski et al. proposed that the total result within the range 11-36 scores should be interpreted as normal, whereas the result below 11 scores would indicate the risk of APD, and the need to refer the child for comprehensive diagnostics of auditory processing disorders [20,22].

The aim of the study was presentation of the psychometric properties of the Polish version of the Children's Auditory Performance Scale, and verification of the usefulness of the tool in the diagnostics of auditory processing disorders.

\section{MATERIALS AND METHOD}

Procedure for preparation of the Polish version of the test. The CHAPS was adapted based on guidelines proposed by Beaton et al. [23]. After obtaining consent from the authors, a qualified translator translated the original version into Polish. The translation re-translation method was applied. Subsequently, a team of specialists was appointed in the fields of: otolaryngology, audiology, logopaedics, and psychometry. The expert team evaluated the translation of each statement separately, using a 5-degree scale with the options from 0 - "inadequate translation" to 5 - "very good translation". Then, after discussion and introduction of expert comments, the final Polish version of the questionnaire was approved.

Respondents. The study included 191 parents of children at school age. Fifteen parents completed the CHAPS questionnaire in an incomplete manner, and their results were removed from further analysis. Therefore, the study group covered 176 parents of 87 girls, and 89 boys. The age of the children ranged from $7-12$ years $(M=8.63 ; S D=1.52)$. The distribution of children was as follows: 7 years -54 children, 8 years $-43,9$ years $-26,10$ years $-28,11$ years 17,12 years -8 children.

Course of the study. The study was conducted in two primary schools in the Warsaw Province. The precondition for participation in the study was obtaining written consent from a parent for a child to participate in the study. During the meeting organized at school, the parents completed the Children's Auditory Performance Scale (CHAPS) and the Scale of Auditory Behaviours (SAB). Using the 
Senses Examination Platform, 3 psychoacoustic tests were performed in the children: the Frequency Pattern Test (FPT), the Dichotic Digit Test (DDT), and the Duration Pattern Test (DPT).

Scale of Auditory Behaviors (SAB) consists of 12 statements, referring to the occurrence of hearing difficulties in a child. The frequency of occurrence of a given behaviour is assessed according to the 5-point Likert scale, from 1 (very frequently) to 5 (never). The results remain within the range from $12-$ 60 scores; the higher the result, the lower the intensity of difficulties with auditory processing. A study by Nunes et al. [15] shows that the mean result for children aged 8-11 is 46 scores. A result below 30 scores may indicate a considerable risk of occurrence of auditory processing disorders, and a detailed diagnostics is recommended. The obtained value of alpha Cronbach is equal 0.93 for the Polish version and indicated a high internal coherence of the tool. The intra-class correlation coefficient (ICC) was 0.95 . Correlation coefficients within the range $0.17-0.68$ of SAB results with the results of other tools confirmed convergent validity [18].

Frequency Pattern Test (FPT) contains 40 sequences of sounds, each consisting of three tones: two tones of the same frequency, and one tone of a different frequency (for a high tone the frequency is $1122 \mathrm{~Hz}$, while for a low tone -880 $\mathrm{Hz}$ ). The task of the examined person is determination of the sequence of the tones heard, e.g. when a high, high, and a low tone were presented subsequently, the correct answer is high, high, low $[3,9]$.

Dichotic Digit Test (DDT) consists of 20 sequences, consisting of two different pairs of numerals from 1-10, which are presented to the examined person at the same time, binaurally. The task is repetition of the numerals heard. The result of the test is the number of correctly repeated numerals, which informs about the degree of maturity of the central auditory system, the way of transmitting information between the hemispheres of the brain, and specialization of the cerebral hemispheres for incoming language stimuli $[3,24]$.

Duration Pattern Test (DPT) consists of 40 sound sequences, each consisting of three tones - two tones of the same length, and one shorter tone (a long tone lasts for $500 \mathrm{~ms}$, a short tone $-250 \mathrm{~s}$ ). The task of the examined person is to specify subsequently the length of tones for each sequence, e.g. if a long, long, short tones were presented, the correct answer is long, long, short $[3,9]$.

Principles of analysis of results. The psychometric and statistical analysis performed was aimed at determination of the reliability of the measurement and validity of the CHAPS questionnaire.

Reliability understood as accuracy of the measurement [25] was estimated in two ways. Internal consistency for subscales and the whole tool was assessed using $\alpha$ - Cronbach coefficient of reliability. The value over 0.70 was considered as evidencing a good internal consistency [26]. Repeatability of the measurement (absolute stability) was assessed by means of intra-class correlation (ICC). After Terwee et al. [27], it was assumed that an ICC value over 0.70 may be considered as satisfactory.
Analysis of validity, understood as the area of application of the test [25], was aimed at investigation whether the CHAPS questionnaire may be applied in the diagnosis of auditory processing disorders. For this purpose, analysis was performed of the correlation between the results of the CHAPS and the results of other tools (SAB questionnaire and psychoacoustic tests). Also, analysis of the differences between groups was performed, differences in the CHAPS results were investigated according to gender and age, and the group of children at risk of APD was compared with the group of children who were not at APD risk. Analysis was performed using non-parametric tests. The MannaWhitney $U$ test was applied to examine the differences between groups, Wilcoxon test to investigate intra-group differences, rho-Spearman rank correlation coefficient to test the relationships between quantitative variables, and $\chi^{2}$ test for independence to examine the relationship between qualitative variables [28].

Analyses were performed using the software IBM SPSS Statistics (version 24). The level of significance was set at 0.05 .

\section{RESULTS}

Table 1 presents basic descriptive statistics and measurements reliability coefficients ( $\alpha$ - Cronbach Cronbach's $\alpha$ ) for results obtained in the CHAPS questionnaire.

Table 1. Descriptive statistics and reliability coefficients for CHAPS scores

\begin{tabular}{lcccccc}
\hline & Min & Max & $\boldsymbol{M}$ & $\boldsymbol{S D}$ & $\boldsymbol{a}$ & $\boldsymbol{r h o}$ \\
\hline Noise & -4.43 & 1.00 & -0.34 & 0.85 & 0.94 & $0.82^{* *}$ \\
\hline Quiet & -3.29 & 1.00 & 0.07 & 0.59 & 0.94 & $0.79^{* *}$ \\
\hline Ideal conditions & -4.33 & 1.00 & 0.26 & 0.64 & 0.94 & $0.58^{* *}$ \\
\hline Multiple Inputs & -4.00 & 1.00 & 0.02 & 0.69 & 0.89 & $0.73^{* *}$ \\
\hline Auditory Memory Sequencing & -3.63 & 1.00 & -0.21 & 0.80 & 0.95 & $0.79^{* *}$ \\
\hline Auditory Attention Span & -3.63 & 1.00 & -0.14 & 0.65 & 0.91 & $0.83^{* *}$ \\
\hline Total & -3.56 & 1.00 & -0.11 & 0.60 & 0.97 & - \\
\hline
\end{tabular}

Min - minimum; Max - maximum; M - mean; SD - standard deviation; $\mathrm{a}$-Cronbach coefficient of reliability; rho - correlation between the results of subscales and the overall result; ${ }^{* *} \mathrm{p}<0.01$

The data presented in Table 1 is evidence that the reliability of measurement was high, both with respect to individual subscales of the questionnaire, and the whole tool. Also, the correlations between the results of individual subscales and the total score were positive, statistically significant and strong, or at least moderate. Parents provided the highest evaluations of hearing and understanding showed by their children in ideal acoustic conditions, while the lowest evaluations - in the situation of noise.

Table 2 demonstrates the comparison of CHAPS results obtained by girls and boys.

Significant difference between girls and boys were found for the subscales Noise and auditory memory, as well as in the total result. In each case, the girls obtained significantly higher results (indicating smaller differences in hearing and understanding), compared to boys. However, the results for the subscales Quiet, Ideal acoustic conditions, Multiple Inputs, and Auditory Memory Sequencing did not significantly differ according to gender. 
Table 2. Comparison of CHAPS scores between girls and boys

\begin{tabular}{lcccccc}
\hline & \multicolumn{2}{c}{ Girls } & \multicolumn{2}{c}{ Boys } & \multirow{2}{*}{$U$} & $p$ \\
\cline { 1 - 5 } & $M$ & $S D$ & $M$ & $S D$ & & \\
\hline Noise & -0.18 & 0.80 & -0.49 & 0.87 & 3070.50 & 0.013 \\
\hline Quiet & 0.11 & 0.52 & 0.03 & 0.64 & 3595.50 & 0.381 \\
\hline Ideal conditions & 0.26 & 0.56 & 0.26 & 0.71 & 3799.00 & 0.812 \\
\hline Multiple Inputs & 0.14 & 0.47 & -0.09 & 0.85 & 3518.00 & 0.248 \\
\hline Auditory Memory Sequencing & -0.04 & 0.64 & -0.38 & 0.90 & 2964.50 & 0.006 \\
\hline Auditory Attention Span & -0.06 & 0.59 & -0.22 & 0.70 & 3401.00 & 0.144 \\
\hline Total & -0.01 & 0.52 & -0.21 & 0.66 & 3176.50 & 0.038
\end{tabular}

$M$ - mean; $S D$-standard deviation; $U$ - result of Manna-Whitney $U$ test; $p$ - level of significance.

CHAPS results in groups of children at different ages. An overall CHAPS result was analyzed according to children's age. Seven-year-old children obtained a mean result: $M=-0.09(S D=0.54)$; eight-year-old children: $M=-0.15$ $(S D=0.41)$; nine-year-old children: $M=-0.28 \quad(S D=1.02)$; ten-year-old children: $M=-0.01(S D=0.62)$; eleven-year-old children: $M=0.03(S D=0.42)$; and twelve-year-old children: $M=-0.01(S D=0.62)$. Polynomial contrast was performed to test whether the total result of CHAPS increases in a linear way with age. The linear trend occurred to be statistically insignificant $(p=0.372)$, which means that there is no relationship consisting in that the youngest children obtain the lowest results, older children - higher results, whereas the oldest children obtain the highest results in CHAPS. This lack of the relationship (increase in results with age) may be observed in Figure 1, which demonstrates confidence intervals for mean CHAPS results in individual age groups. Figure 2 presents an exemplary individual profile of auditory functioning of a 9-year-old patient.

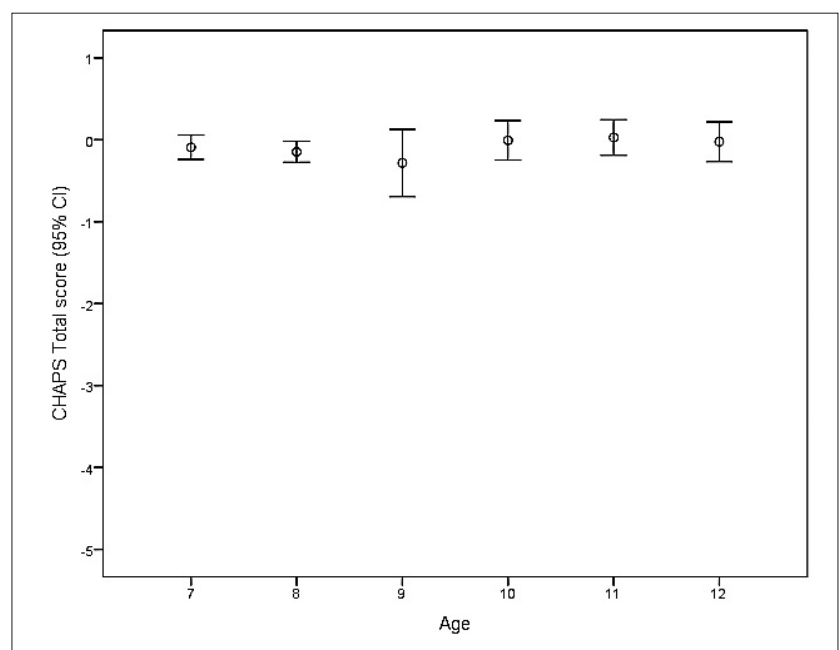

Figure 1. Confidence intervals $(\mathrm{Cl})$ for the mean CHAPS scores in children of different ages

Table 3 presents correlations between CHAPS results and the results of the SAB questionnaire, and results of FPT, DPT and DDT tests.

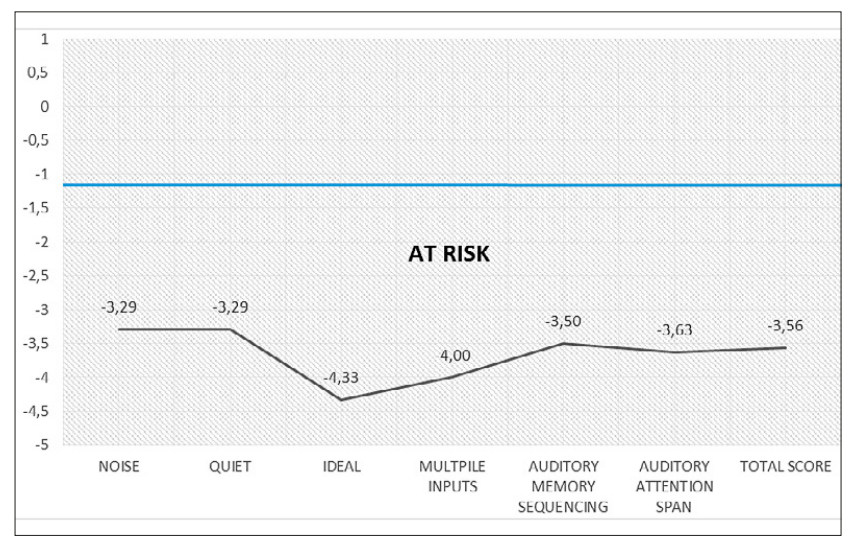

Figure 2. Individual profile of auditory functioning of a 9-year-old patient - an example

Table 3. Correlations between CHAPS scores. SAB scores and results of psychoacoustic tests

\begin{tabular}{lccccc}
\hline & SAB & FPT & DPT & DDT UL & DDT UP \\
\hline Noise & $0.58^{* *}$ & $0.18^{*}$ & $0.28^{*}$ & $0.32^{* *}$ & 0.07 \\
\hline Quiet & $0.50^{* *}$ & $0.15^{*}$ & $0.17^{*}$ & $0.25^{* *}$ & 0.13 \\
\hline Ideal conditions & $0.29^{* *}$ & 0.14 & 0.09 & 0.10 & 0.04 \\
\hline Multiple Inputs & $0.38^{* *}$ & 0.05 & 0.06 & 0.12 & 0.07 \\
\hline Auditory Memory Sequencing & $0.53^{* *}$ & $0.20^{* *}$ & $0.29^{* *}$ & $0.25^{* *}$ & 0.07 \\
\hline Auditory Attention Span & $0.55^{* *}$ & $0.18^{*}$ & $0.18^{*}$ & $0.18^{*}$ & 0.06 \\
\hline Total & $0.62^{* *}$ & $0.20^{*}$ & $0.24^{* *}$ & $0.28^{* *}$ & 0.10 \\
\hline
\end{tabular}

${ }^{* *} p<0.01 * p<0.05 ;$ SAB - Scale of Auditory Behaviours); FPT - Frequency Pattern Test; DPT Duration Pattern Test; DDT -Dichotic Digit Test; RE - right ear; LE - left ear.

The data presented in Table 3 indicate that there is a significant, positive correlation of a moderate strength between the total result of CHAPS, and total result of SAB questionnaire; the smaller difficulty with understanding and hearing shown by a child in parent's opinion in CHAPS questionnaire, the lower the frequency of auditory disorders demonstrated by the child in the SAB questionnaire. Also, the results obtained in the subscales of CHAPS are significantly and positively correlated with the total SAB result.

Significant, positive correlations were also confirmed between the total result of the CHAPS questionnaire, and the results of psychoacoustic tests: FPT. DPT and DDT, while in the case of the last test, the relationship occurred only for the result obtained for the left ear, with the lack of the relationship for the right ear. Similar correlations were also found for the subscales: Noise, Quiet, Auditory Memory Sequencing, and Auditory Attention Span; however, similar to the total result, the strength of these correlations was not considerable.

Repeatability of measurement. Test re-test results were obtained from four parents. In this group, the total CHAPS result in the first measurement was $M=-0.65(S D=1.15)$, on average, while in the second measurement in re-test it was $M=-0.28(S D=0.53)$, on average. Wilcoxon test for dependent samples did not show any difference between the two measurements: $Z=1.07 ; p=0.285$. Repeatability of the measurement was assessed using intra-class correlation coefficient, and was $I C C=0.84$. 
Determination of CAPD risk based on the CHAPS overall aggregate score overall. In the examined group, the CHAPS overall aggregate score was from -128 to 36 points $(M=-3.81$; $S D=21.75)$. By applying the criterion proposed by Smoski et al. [20], two groups of children were selected: at risk of APD, and not at risk of APD. The group of risk included 44 children, whereas the group not at risk - 132 children. In the group at risk, the majority were boys - 28 (64\%), whereas in the group not at risk the majority were girls, and 61 (46\%) boys. The difference between groups according to gender was statistically significant: $\chi^{2}(1)=4.01 ; p=0.045$. Children from the group at risk were aged 8.73 years, on average, $(S D=1.58)$, while children from the group not at risk were at a similar age -8.34 years, on average, $(S D=1.28)$. The difference according to age was statistically insignificant: $U=3250.50 ; p=0.124$.

The results obtained by children from the group at risk and children not at risk in the SAB questionnaire and psychoacoustic tests were compared (Tab. 4).

Table 4. Comparison of SAB scores and psychoacoustic tests results between children at-risk and not at risk for APD

\begin{tabular}{|c|c|c|c|c|c|c|}
\hline & \multicolumn{2}{|c|}{ Group at risk } & \multicolumn{2}{|c|}{ Group not at risk } & \multirow{2}{*}{ U } & \multirow{2}{*}{$p$} \\
\hline & $M$ & $S D$ & M & $S D$ & & \\
\hline SAB & 36.95 & 9.74 & 49.68 & 7.40 & 848.50 & $<0.001$ \\
\hline FPT & 44.94 & 21.41 & 52.06 & 24.51 & 2154.50 & 0.082 \\
\hline DPT & 54.29 & 23.17 & 65.17 & 25.65 & 1900.00 & 0.009 \\
\hline DDT LE & 58.61 & 19.19 & 68.86 & 20.56 & 1812.50 & 0.001 \\
\hline DDT RE & 82.21 & 14.44 & 83.13 & 13.99 & 2582.0 & 0.646 \\
\hline
\end{tabular}

$\mathrm{M}$ - mean; SD - standard deviation; $\mathrm{U}$ - result of Manna-Whitney U test; $p$ - level of significance SAB - Scale of Auditory Behaviours; FPT - Frequency Pattern Test; DPT -Duration Pattern Test; DDT -Dichotic Digit Test. RE - right ear; LE - left ear.

Based on the data presented in Table 4 it may be presumed that children from the group at risk, compared to those from the group not at risk, obtained significantly lower results in DPT test, and in DDT test (left ear), as well as in the $\mathrm{SAB}$ questionnaire. The result in FPT test was also lower in children from the group at risk; however, the difference was significant on the level slightly higher than that assumed $(p=0.082)$. In DDT test (right ear) children from both groups obtained similar results.

\section{DISCUSSION}

Questionnaires applied in the diagnostics of auditory processing disorder not only serve as screening tools, but are also a source of information about the auditory functioning of a child in conditions of daily life, enrich the set of information concerning the child by the perspective of people who know them well, and observe them in natural situations (parents, caregivers, teachers) [16]. It is also an important fact that the questionnaires allow the acquisition of data in a low-cost, and not time-consuming way. Similar to any other tool used in the diagnostic process, a questionnaire should also be reliable, enable a reliable measurement, and be a valid measure of the examined phenomenon. The performed process of adaptation and validation of the CHAPS questionnaire was aimed at verification of its psychometric properties, and determination of its usefulness in the diagnostics of auditory processing disorders.
The results of own study demonstrate that the reliability of the measurement using the CHAPS questionnaire was high. For the subscales it was 0.89 (subscale Multiple Inputs) - 0.95 (subscale Auditory Memory Sequencing), whereas for the whole tool the reliability indicator was $\alpha=0.97$. Positive, statistically significant correlations between the results of subscales and the total result also evidence good reliability. The lowest correlation was obtained for the subscale Ideal conditions ( $r h o=0.58$ ), which may be explained by the fact that in this subscale (hearing and understanding in a silent room, face-to-face, with good eye contact), the youngest children showed the least difficulties. Similarly, the authors of the CHAPS questionnaire found that the results of this subscale were most weakly correlated with the total result $(r=0.67)$ [29]. This was also confirmed in the study by Illiadou and Bamiou [30]. The correlations between the results of the remaining subscales and the total result were above 0.7 , evidencing high internal coherence of the tool.

Another aspect of reliability of measurement is repeatability, in other words, stability of results obtained during measurement using the same tool with a certain intervening interval. Its assessment was satisfactory, although it should be emphasized that the group of respondents tested twice was not large, which resulted from organizational conditioning. No statistically significant difference was confirmed between the results of test and re-test, similar to investigations in the original version [29], and intra-class correlation coefficient was $I C C=0.84$, which evidenced that the results of measurement by means of the CHAPS questionnaire show a satisfactory stability.

The results obtained in the CHAPS questionnaire by the study group were relatively high - within the range $+1-$ -5 and, on average, oscillated around zero, i.e. the parents generally assessed that their children demonstrate a similar level of difficulty with hearing and understanding as their contemporaries. The study was conducted in primary schools, and the examined group was not a clinical group, which may explain the relatively high level of results. However, it should be noted that the differences between results were considerable, standard deviations were higher than the mean values, which evidences that there occurred significant differences in difficulties with hearing and understanding shown by children. Illiadou and Bamiou [30] compared CHAPS results obtained by children with the diagnosis of APD, and those not diagnosed for APD, who did not show learning difficulties, and attended public schools. Their study demonstrated that children from the control group obtained significantly higher results than children with APD in all six subscales, which confirms validity of the CHAPS. Relatively similar results were obtained by Ferguson et al. [31] who found that children with APD obtained significantly lower results than children from the control group in the subscales: Multiple Inputs, Auditory Attention Span, Auditory Memory Sequencing; however, in the subscales Quiet and Ideal conditions, the results in both groups did not differ significantly. It would be worth conducting a similar study comparing difficulty with understanding and hearing by children with APD and without APD in Polish conditions.

It was confirmed that in the CHAPS questionnaire boys obtained lower result than girls in the subscales Noise, Auditory Memory Sequencing, and in general. Szkiełkowska et al. [32] found that the level of auditory skills of children did not differ according to gender; however, this resulted 
from the comparison between the levels of performance of psychoacoustic tests FPT and DPT. In the CHAPS questionnaire applied in own study, where parents described auditory functioning of their children, boys obtained lower results.

The SAB questionnaire (Skarżyński et al., 2019) is recommended as a screening tool in the diagnosis of APD in Polish children. It was confirmed that the results obtained in CHAPS and SAB were relatively similar, on the general level a positive, statistically significant correlation between these tests was observed $(r h o=0.62)$. The total CHAPS score, and the results in the subscales Noise, Quiet, Auditory Memory, and Auditory Attention Span, significantly correlated with the results of psychoacoustic tests: FPT. DPT and DDT. In the case of the DDT test, a relationship was observed only for the result obtained for the left ear, while no relationship was noted for the right ear, which may be due to the phenomenon defined as the 'right ear advantage' (REA) [33-34].

Correlations with the results of psychoacoustic tests were weak, and generally remained within the range 0.2-0.3. Weak correlations between the results of the CHAPS and the results of psychoacoustic tests were also reported by Wilson et al. [35], while in a study by Illiadou and Bamiou [30],the these correlations were higher, mostly within the range $0.3-0.5$. These discrepancies may result from children's age, because attention is paid to the fact that the parents of younger children have lower expectations with respect to them, and provide more optimistic assessments of their hearing and understanding skills, whereas parents of older children perceive the skills of their children in a more realistic way. In turn, psychoacoustic tests precisely reflect the level of auditory skills of a child. This explanation is supported by the fact that own study did not demonstrate that the CHAPS results obtained by children at different age significantly differ, while such an increase should be observed with age. Illiadou and Bamiou [30] even proposed the application of the CHAPS in older children, aged 12 and over, in order to avoid the potentially interfering effect of age on the results of the questionnaire.

Guided by the criterion proposed by the authors of the questionnaire, a group of children was distinguished at risk of APD (who obtained results below 11 scores), and a group of children not at risk of APD, and subsequently the levels of their performance in psychoacoustic tests were compared. According to expectations, these levels were significantly higher in children not at risk of APD, although the expected difference did not occur in all tests. It was observed in DPT and DDT tests (but only for the left ear). No statistically significant difference was observed in the DDT test for the right ear, which may result from generally better results for the right ear, while in the case of FPT test, the difference did not reach the assumed level of statistical significance $(p=0.082)$. Nevertheless, the criterion proposed by Smoski et al. [29] seems to be useful.

Summing up, the CHAPS questionnaire enables a reliable measurement of difficulty with hearing and understanding shown by children, and may be useful in the diagnostics of APD. It may be recommended for use at a preliminary stage, when it is necessary, in a quick and cheap way, to select children who may show the symptoms of auditory processing disorders, and refer them to specialist, comprehensive examinations.

\section{CONCLUSIONS}

The results of statistical and psychometric analyses indicate that the Polish version of the CHAPS questionnaire enables a reliable measurement of difficulty with hearing and understanding in children. The questionnaire may be useful in the diagnostics of auditory processing disorders.

\section{Acknowledgements}

This paper is published within the framework of the project entitled "Integrated system of tools designed for diagnostics and telerehabilitation of the sense organs disorders (hearing, vision, speech, balance, taste, smell)" INNOSENSE, co-financed by the National Centre for Research and Development within the STRATEGMED Programme.

\section{REFERENCES}

1. ASHA Working Group of Auditory Processing Disorders. (Central) Auditory Processing Disorders. Technical Report. American SpeechLanguage-Hearing Association; 2005. https://www.asha.org/policy/ TR2005-00043 (dostęp:26.03.2020).

2. Muzyka-Furtak E. Surdologopedia. Teoria i Praktyka. Gdańsk: Wydawnictwo Harmonia; 2015.

3. Czajka N, Grudzień D, Pluta A, Kurkowski ZM, Ganc M, Cieśla K, et al. Efekty terapii Stymulacji Percepcji Słuchowej (SPS-S) u dzieci z zaburzeniami koncentracji uwagi słuchowejoraz centralnymi zaburzeniami przetwarzania słuchowego. Now Audiofonol. 2012; 1(1): 79-86.

4.Dajos-Krawczyńska K, Piłka A, Jędrzejczak WW, Skarżyński H. Diagnoza zaburzeń przetwarzania słuchowego- przegląd literatury. Now Audiofonol. 2014; 2(5): 9-14.

5. Barry JG, Tomlin D, Moore DR, Dillon H. Use of Questionnaire-Based Measures in the Assessment of Listening Difficulties in School-Aged Children. Ear Hear. 2015;36(6):e300-e313. doi: 10.1097/AUD.0000000000000180

6. Bamiou DE, Musiek FE, Luxon LM. Aetiology and clinical presentations of auditory processing disorders-a review. Arch Dis Child. 2001; 85(5): 361-365. http://dx.doi.org/10.1136/adc.85.5.361

7. Musiek FE, Gollegly KM, Lamb LE, Lamb P. Selected issues in screening for central auditory processing dysfunction. Seminars in Hearing. 1990; 11(4): 438-445.

8. Paczkowska A, Marcinkowski JT. Istota zaburzenia przetwarzania słuchowego- niedocenianego problemu zdrowotnego. Hygeia Public Health. 2013; 48(4): 396-399.

9. Włodarczyk E, Szkiełkowska A, Skarżyński H, Miaśkiewicz B, Skarżyński PH. Reference values for psychoacoustic tests on Polish school children 7-10 years old. PLOS ONE. 2019; 14(8): e0221689. https://doi.org/10.1371/journal.pone.0221689

10. Skoczylas A, Cieśla K, Kurkowski ZM, Czajka N, Skarżyński H. Diagnoza i terapia osób z centralnymi zaburzeniami przetwarzania słuchowego w Polsce. Now Audiofonol. 2012; 1(3): 51-55.

11. British Society of Audiology. Position Statement and Practice Guidance Auditory Processing Disorder; 2017. http://www.thebsa.org.uk/wpcontent/uploads/2017/04/APD-Position-Statement-Practice-GuidanceAPD-2017.pdf (dostęp: 26.03.2020).

12. Majak J. Trudności diagnostyczne w zaburzeniach przetwarzania słuchowego u dzieci. Otolaryngologia. 2013; 12(4): 161-168.

13. Samsonowicz K, Skoczylas A, Fludra M, Geremek-Samsonowicz A. Trudności językowe i szkolne u 8-letniego chłopca z zaburzeniami przetwarzania słuchowego - studium przypadku. Now Audiofonol. 2014; 3(4): 47-54.

14. Szkiełkowska A, Włodarczyk E, Senderski A, Skarżyński H, Ganc M, Piłka A. Ocena procesów przetwarzania słuchowego u dzieci z dyslalią. Otolaryngol Pol. 2009; 63(1): 54-57.

15. Nunes CL, Pereira LD, de Carvalho GS. Scale of Auditory Behaviors and auditory behavior tests for auditory processing assessment in Portuguese children. CoDAS. 2013; 25(3): 209-215.

16. Krzeszewska P, Kurkowski ZM. Przydatność wybranych kwestionariuszy przesiewowych do wykrywania zaburzeń ośrodkowego przetwarzania słuchowego. Now Audiofonol. 2015; 4(3): 51-54. doi: 10.17431/894767 
17. Jordan A, Ptaszkowska A, Kurkowski ZM. Testy oceniające celowość zastosowanych wzmocnień dźwięków w klasie i w domu kwestionariusze ECLB i CHILD oraz możliwości ich zastosowania. Now Audiofonol. 2015; 4(3): 55-61.

18. Skarżyński H, Bieńkowska K, Gos E, Grudzień D, Skarżyński PH, Czajka N, Wołujewicz K, Włodarczyk E. Cross-Cultural Adaptation of the Scale of Auditory Behaviors Questionnaire. Lang Speech Hear Ser. 2019; 50(4):683-692.https://doi.org/10.1044/2019_LSHSS-19-0014

19. Musiek FE, Chermak G. Handbook of (Central) Auditory Processing Disorder: Auditory Neuroscience and Diagnosis. Vol. 1. 2nd ed. San Diego: Plural Publishing. 2014. p. 272-273.

20. Smoski WJ, Brunt MA, Tannahill JC. Children's Auditory Performance Scale (CHAPS). https://wwwl.phonakpro.com/content/dam/ phonakpro/gc_hq/en/resources/counseling_tools/documents/ child_hearing_assessment_childrens_auditory_performance_scale_ chaps_2017.pdf (dostęp: 17.04.2020).

21. Schow R, Seikel A. Screening for (Central) Auditory Processing Disorder. In: Musiek FE. Chermak G. (eds). Handbook of (Central) Auditory Processing Disorder: Auditory Neuroscience and Diagnosis Vol. 1. 2nd ed. San Diego: Plural Publishing. 2007. p. 137-155.

22. Sharma M, Purdy SC, Humburg P. Cluster Analyses Reveals Subgroups of Children With Suspected Auditory Processing Disorders. Front. Psych. 2019; 10:2481. https://doi.org/10.3389/fpsyg.2019.02481

23. Beaton DE, Bombardier C, Guillemin F, Ferraz MB. Guidelines for the process of cross-cultural adaptation of self-report measures. Spine. 2000; 25(24): 3186-3191.

24. Skarżyński PH. Włodarczyk AW, Kochanek K, Piłka A, Jędrzejczak WW, Olszewski Ł, Bruski Ł, Niedzielski A, Skarżyński H. Central auditory processing disorder (CAPD) tests in a school-age hearing screening programme- analysis of 76.429 children. Ann Agric Environ Med. 2015; 22(1): 90-95. https://doi.org/10.5604/12321966.1141375

25. Hornowska E. Testy psychologiczne. Teoria i praktyka. Warszawa: Wydawnictwo Naukowe Scholar; 2014.
26. Nunnally JC, Bernstein IH. Psychometric theory. New York: McGrawHill. 1998.

27. Terwee CB, Bot SD, de Boer MR, van der Windt DA, Knol DL, Dekker J, Bouter LM, et al. Quality criteria were proposed for measurement properties of health status questionnaires. J Clin Epidemiol. 2007; 60: 34-42. doi: 10.1016/j.jclinepi.2006.03.012

28. Field A. Discovering statistics using IBM SPSS Statistics. London: SAGE. 2013.

29. Smoski WJ, Brunt MA, Tannahill JC. Listening characteristics of children with central auditory processing disorders. Lang Speech Hear Serv Sch. 1992; 23: 145-52.

30. Illiadou V. Bamiou DE. Psychometric Evaluation of Children With Auditory Processing Disorder (APD): Comparison with NormalHearing and Clinical Non-APD Groups. J Speech Lang Hear Res. 2012; 55: 791-99. doi: 10.1044/1092-4388(2011/11-0035)

31. Ferguson MA, Hall RL, Riley A, Moore DR. Communication. listening. cognitive and speech perception skills in children with auditory processing disorder (APD) or specific language impairment (SLI). J Speech Lang Hear Res. 2011; 54: 211-27. https://doi.org/10.1044/1092 4388(2010/09-0167)

32. Szkiełkowska A, Włodarczyk E, Piłka A. Wartości referencyjne wybranych testów słuchowego przetwarzania czasowego dla dzieci polskich w wieku szkolnym. Otolaryngol Pol. 2018; 72(6): 31-36. doi: 10.5604/01.3001.0012.4366

33. Hughdal K. Dichotic listening in the study of the auditory laterality. In: The Asymmetrical Brain. Hughdal K, Davidson J, eds. Cambridge: MIT Press. 2003. p. 441-75.

34. Bless JJ, Westerhausen R, von Koss Torkildsen J, Gudmundsen M, Kompus K, Hugdahl K. Laterality across languages: Results from a global dichotic listening study using a smartphone application. Laterality. 2015; 20(4): 434-52.

35. Wilson WJ, Jackson A, Pender A, Rose C, Wilson J, Heine C, et al. The chaps sifter and taps-r as predictors of (C)ap skills and (C)apd. J Speech Lang Hear Res. 2011; 54: 278-91. 